\title{
Apresentação do Dossiê
}

\section{Instituições Judiciais na América Latina: o desafio de convergir agendas de pesquisa}

Embora abriguem configurações sócio-históricas e sócio-políticas distintas, os países latino-americanos possuem traços históricos e políticos que favorecem uma agenda comum para os estudos das relaçôes entre Judiciário e política. A construção do sistema judicial é permeada pela herança de estruturas institucionais importadas da Europa e dos Estados Unidos e pelas diferentes estratégias de ascensão e manutenção do poder político das elites locais.

Um primeiro conjunto de questóes trazidas por pesquisadores que póem em pauta as relações entre o Judiciário e a política, nas últimas duas décadas, na América Latina concerne à relação entre autoritarismo político e justiça. Tal perspectiva evidencia que os regimes autoritários investiram no sistema judicial restringindo o espaço de sua autonomia e buscando construir uma legitimidade jurídica para seus atos de força. Nessa linha, é destacada a importância de estudar os diversos mecanismos utilizados pelo poder militar para restringir a autonomia do Judiciário, como o fortalecimento da justiça militar e a repressão da oposiçáo aos regimes. A proliferação das comissões da verdade que possibilitam a abertura para novas fontes de documentos sobre os períodos autoritários dos países latino-americanos, também contribuem para o aumento do interesse nos estudos que tomam como objeto as relações entre o Judiciário, suas elites e a legitimidade dos regimes militares.

Em sentido inverso, outros autores demonstram a articulação através da mobilização do sistema judicial, da resistência aos regimes autoritários, por redes calcadas em ONGs e advogados ativistas. A partir desses movimentos, foram produzidas doutrinas jurídicas que viriam a repercutir nas novas constituiçóes e reformatar a ordem jurídico-política dos países latino-americanos quando da passagem para os regimes democráticos. Para além do período das ditaduras, essas redes obtiveram êxito em diferentes graus e contextos em consolidar nas constituições democráticas a proteção de direitos e garantias individuais e políticas.

Um terceiro eixo de questôes e problemas que circunda as relaçóes entre justiça e política na América Latina aborda em perspectiva comparada as configurações da repercussão política do Judiciário, já no período pós-regimes militares. As pesquisas evidenciam, em diferentes perspectivas analíticas, o fenômeno do protagonismo do poder judicial e sua crescente imbricação com o espaço da política. Nota-se que, para além do aparecimento de questóes recorrentes de temas políticos em democracias ocidentais, como a crescente mobilização do Judiciário por 
grupos de interesse, ou por grupos políticos, destaca-se a emergência do Judiciário enquanto promotor da justiça social com forte judicialização da legislação social muito peculiar ao contexto latino-americano.

Ainda pode-se destacar, sobre a relação entre justiça e poder político na América Latina, uma agenda de estudos que busca relacionar movimentos de internacionalização do campo jurídico e as iniciativas de reforma do direito e das instituições judiciais nos países latino-americanos. Os trabalhos buscam avançar hipóteses sobre as iniciativas de reformas do sistema judicial tanto em contextos autoritários, como nos cenários pós-redemocratização. Uma gama importante de estudos, de viés institucionalista, busca investigar o tema da independência e do empoderamento judicial. Em países cujas experiências autoritárias foram formalmente superadas, questiona-se até que ponto garantias institucionais resultam em atuações efetivamente independentes dos órgãos do sistema de justiça.

O presente Dossiê Instituições Judiciais e Política na América Latina pretende dar uma contribuição para a convergência da agenda sobre essa temática reunindo pesquisas de diferentes enfoques analíticos e trazendo a contribuição de pesquisadores do México e da Venezuela. É composto em parte de artigos de autores que participaram do Colóquio Instituições Judiciais e Debates Político na América Latina promovido pelo Núcleo de Estudos em Justiça e Poder Político do Programa de PósGraduação em Ciência Política da Universidade Federal do Rio Grande do Sul, em maio de 2014.

O Dossiê abre com o artigo de Rogelio Perdomo, Represión y justicia en Venezuela en tiempos de protesta, em que o autor discute a relação entre a violação de direitos humanos e o sistema judicial na Venezuela frente ao cenário de recentes manifestações públicas, trazendo para o centro do debate a relação entre práticas autoritárias e a distribuição da justiça.

$\mathrm{O}$ artigo de Azul A. Aguiar-Aguilar, Os direitos humanos e o controle de convencionalidade no México, aborda a evolução da proteçáo dos direitos humanos no México a partir da nova interpretação judicial da Suprema Corte de Justiça que permitiu o uso do controle de convencionalidade, permitindo que juízes federais e estaduais verifiquem a conformidade das leis nacionais com o que estabelece a Convenção Interamericana de Direitos Humanos. A autora indaga, até que ponto os atores nacionais estáo protegendo os direitos humanos no México e mobilizando esse novo instrumento.

O artigo de Lígia Mori Madeira, STF como ator politico no Brasil: o papel do tribunal na implementação de políticas sociais entre 2003 e 2013, aborda a atuação do Supremo Tribunal Federal como um ator que interfere na formulação e 
implementação das políticas sociais no Brasil, especialmente atuando como ator com poder de veto ou agindo como um parceiro do Executivo Federal em relação aos programas e políticas sociais.

$\mathrm{O}$ artigo de Débora Alves Maciel e Andrei Koerner, O processo de reconstrução do Ministério Público na transição política (1974-1985), analisa a dinâmica da reconstrução do Ministério Público no Brasil, focalizando a mobilização de promotores e de procuradores de justiça, no período de 1974-1985. Conforme os autores, as características da transição política brasileira foram decisivas para o processo de mudança da instituição que ganhou status constitucional em 1988. A liberalização do regime militar modificou os vínculos entre juristas, oposição partidária e movimentos pró-democracia. Os autores demonstram como a conexão do movimento institucional com as elites políticas dissidentes e a densa rede de ativismo em torno de novos conflitos sociais permitiu ao Ministério Público experimentar novas estratégias de ação coletiva e ganhar visibilidade política no Brasil.

O artigo de Rebecca Magalhães e Ernani Carvalho, Há um desenho institucional favorável à independência judiciária? Um panorama das constituiçôes vigentes na América Latina, indaga se há um desenho institucional favorável à independência judiciária nas constituiçôes vigentes da América Latina. A partir de um estudo comparativo, os autores pontuam que fatores institucionais parecem impactar a independência e poder das cortes e, portanto, frequentemente são utilizados para explicar seu comportamento. Mecanismos como composição das cortes, jurisdição, seleção dos membros e tempo do mandato comumente figuram detalhadamente nos textos constitucionais, sinalizando que a autonomia das cortes é tradicionalmente um ideal desejável pelos constituintes latino-americanos.

O artigo de José Paulo Martins Junior, Emilie Kalyne Munhoz e Matheus Cavalcanti Pestana, Legislativo versus Judiciário, analisa as relaçóes entre poderes a partir dos conflitos em torno da definição das regras eleitorais no Brasil. Os autores tomam como caso representativo da declaração de inconstitucionalidade da cláusula de desempenho, definida no artigo 13 da Lei 9096/95.

$\mathrm{O}$ artigo de Lígia Barros de Freitas, O poder político da ANAMATRA e a Lei Constitucional, tem por foco a atuação política da Associação Nacional dos Magistrados da Justiça do Trabalho (ANAMATRA) no processo constituinte de 1987-88 e na Reforma do Poder Judiciário em 2004. A autora demonstra que os ganhos que ANAMATRA obteve no processo da Emenda Constitucional da Reforma do Poder Judiciário advieram da sua atuação anterior na Assembleia Nacional 
Constituinte de 1987-1988 e de sua atuação conjunta com o Tribunal Superior do Trabalho (TST).

O artigo de Enivaldo Carvalho da Rocha, Dalson Brito Figueiredo Filho, José Alexandre da Silva Júnior, Ranulfo Paranhos, Pawan Kumar e Erinaldo Ferreira do Carmo, Capacidade institucional e corrupçáo: Tribunais de Contas Estaduais em perspectiva comparada, analisa a relação entre a capacidade institucional dos Tribunais de Contas Estaduais e corrupção. Os autores sugerem no artigo que comparativamente Sáo Paulo apresenta o Tribunal com maior capacidade institucional, enquanto Mato Grosso do Sul apresenta o pior desempenho; também apontam que em média, quanto maior orçamento do Tribunal, menor é o nível de transparência e, quanto maior a capacidade institucional do Tribunal, maior é a probabilidade de detectar corrupção.

Partindo também de uma abordagem cruzada entre estados da federação no Brasil, o artigo de Marcio Camargo Cunha Filho, Judicialização e competição em análise subnacional: os casos do Rio Grande do Sul e Ceará, testa, no plano da política subnacional brasileira, a hipótese de que a judicialização da política está associada à competição política, apresentando abordagem que associa a judicialização a fatores exógenos às instâncias judiciais. Analisam-se dados empíricos referentes à intervenção do Supremo Tribunal Federal (STF) nas políticas estaduais do Rio Grande do Sul e do Ceará, estados que apresentam elevados e reduzidos níveis de competição, respectivamente. $\mathrm{O}$ autor verifica que a judicializaçáo, medida pelo número de intervenções do STF na política estadual através de Ações Diretas de Inconstitucionalidade (ADIs), é mais elevada no Rio Grande do Sul.

Os organizadores:

Fabiano Engelmann

(Universidade Federal do Rio Grande do Sul/ Brasil)

Lígia Mori Madeira

(Universidade Federal do Rio Grande do Sul/ Brasil) 